\title{
1 \\ Path to the Ministry of Foreign Affairs
}

\section{The Lineage of the Shidehara Family}

The forty-fourth prime minister of Japan, Shidehara Kijūrō, was born in the village of Kadoma, Osaka, on 11 August $1872 .{ }^{1}$ Today, the village of Kadoma has become a city. While it now flourishes as the home of the Panasonic Corporation, it was originally a wetland. Even today, there remain various places within the city limits where vestiges of lotus root fields can be seen. As a wetland area, Kadoma has long suffered from flooding. In fact, the flood of the nearby Yodogawa River in 1885 dealt the Shidehara family a particularly heavy blow.

These circumstances delayed the development of Kadoma considerably. It was not until 1910 that the Keihan Train Line opened between Tenmanbashi in Osaka and Gojō in Kyoto. By 1912 (the beginning of the Taishō era), however, electric lighting began to be installed, and the Great Consolidated Electric Company constructed a transformer substation at Osaka. Finally, in 1933, Panasonic opened its headquarters and factory at Kadoma.

The Shidehara household, which accrued its wealth through farming, became the most prosperous in the village. The family lineage could be traced back at least as far as the eighteenth century. It is said that they were originally located in nearby Kyoto and later moved to Kadoma. ${ }^{2}$ Various records about the Shidehara household remain at the Kadoma City Historical Archive, comprising some 520 documents. These include crop 
production records, ledgers, notebooks, and other documents pertaining to village administration, household affairs, construction, family register (koseki) population, etc. The majority of these documents are from modern times. For this reason, there are not many that relate directly to Kijūrō. Nevertheless, these records on the Shidehara household remain valuable for understanding Kijūrō's roots. ${ }^{3}$

While the home of Kijūrō's birth no longer exists, a street corner of Kadoma City, Ichiban-cho, bears a plaque dedicated to Kijūrō's oldest brother, Taira, and to Kijūrō's siblings. The plaque is signed by Kijūrō’s junior at the Ministry of Foreign Affairs-Yoshida Shigeru, another future prime minister. Given the lineage of the Shidehara household, Kijūrō's future life and career might seem quite surprising. Kijūrō, after all, came from a farming family in an underdeveloped area. How did such a child go on to reach the very top of Japanese politics?

\section{Home Environment}

The key to unlocking this mystery is Kijūrō's home environment. His father, Shidehara Shinjirō, had married into the family from the Ichikawa household of Shimoshima-gashira, also located in Kadoma. Kijūrō's mother was Shidehara Kuichirō's eldest daughter, Shizu. As Shizu was the only child of Kuichirō, a large landowner, Kuichirō adopted Shinjirō. Shinjirō was also the primary assistant of the head of the village. While responsible for managing a wealthy farming household, Shinjirō was also extremely committed to the education of his two sons, Taira and Kijūrō, and two daughters. In this regard, Shinjirō's wife, Shizu, was also supportive. Taira, who was two years older than Kijūrō, was a quiet, bookish child, regarded as intelligent from a young age. He would go on to study national history at the Imperial University of Tokyo. After becoming principal of the Yamanashi Prefectural Junior High School and a professor at the Higher Normal School in Tokyo, Taira would eventually be appointed as the library bureau director for the Ministry of Education.

Here I would like to speak about Taira in more detail. This is because he was the individual who eventually laid the foundations for the colonial education system in Korea and Taiwan. As a parliamentary councillor on educational policy for the Korean government, Taira strived to establish a system of education in Korea in the middle of the decade following 
1900. When Taiping Imperial University was established in 1928, Taira was appointed the first president. After the war, during the US occupation of Japan, Taira also decided upon changes to the constitution in his role as privy councillor. As an individual who was highly conversant with issues surrounding national borders, he also argued in a 1951 paper titled 'Tsushima Mondai' (The Tsushima problem) that Tsushima Island 'was part of Japanese territory from long ago' ${ }^{4}$

Taira also authored numerous publications on topics such as East Asian history and colonial education. One of these is titled Daitóa no Seiiku (The development of Greater East Asia). The preface to this text was written by Ishibashi Tanzan (1884-1973), the fifty-fifth prime minister of Japan. While Ishibashi was originally from Tokyo, he attended elementary and middle school in Yamanashi prefecture. According to the preface, when Ishibashi attended Yamanashi Prefectural Junior High School in Kofu City, 'my former teacher, Shidehara sensei', arrived to serve as school principal. Afterwards, Ishibashi would have the opportunity to meet with Shidehara Taira at the middle school alumni association known as the Tachibana Society. He writes that he found Taira's manner of speaking engrossing and that Taira displayed a deep knowledge of the various problems regarding Japan's overseas territories. Ishibashi, deeply impressed by these qualities, urged Taira to put together a lecture. This is how Ishibashi came to help Taira publish his book Daitöa no Seiiku through Tōyō Keizai Shinpōsha. At the time, Ishibashi was the president and chief executive officer of the company. ${ }^{5}$

Taira and Kijūrō also had two younger sisters, Misao and Setsu. Misao, who was a midwife, had her husband, a doctor, take her family name, and together they opened the Shidehara Clinic in Kadoma. Misao was also involved with social welfare. After her husband died, it was her younger sister, Setsu, who took over the Shidehara Clinic. Setsu was actually the first female doctor in Osaka Prefecture. However, it was not easy to be a female doctor in conservative Kadoma. Setsu eventually became disillusioned, left Kadoma, and set up a new clinic in Mikagekishimoto, in Kōbe City. Setsu's mother, Shizu, died young due to complications after giving birth. Setsu, therefore, treated her older sister Misao almost like a mother. Setsu never married, focusing instead on her work as a doctor and later adopting Misao's grandchild. After she died, the Shidehara Clinic closed. 


\section{The Diplomatic Service Exam}

So, we come to Kijūrō himself. Compared to his older brother, Taira, young Kijūrō was an unruly child. According to their father, Shinjirō, while Taira would diligently study the Chinese classics, Kijūrō preferred 'the new subjects'. He wrote:

The school principal also held out great hopes for their futures and expended a great deal of energy on their behalf. After graduating from elementary school, he helped Taira enter the junior and senior high school that was in Osaka Otemae at that time, at the recommendation of [Confucian scholar] Fujisawa Nangaku sensei. ${ }^{6}$

Kijūrō followed in his older brother's footsteps, attending Osaka Middle School.

Osaka Middle School was known for its English-language education. Matsui Keishirō (1868-1946), who would later serve as foreign minister, was Kijūrō's senior at the school. Eventually, Osaka Middle School would be renamed the Third Higher Middle School, one of the top-level schools in Japan at the time, which fed students into the Imperial University of Tokyo and careers in the bureaucracy. While Shidehara was still attending the school, it was relocated from Osaka to Kyoto. The future politician Izawa Takio (1869-1949) and future prime minister Hamaguchi Osachi (1870-1931) were also attending the school at this time. ${ }^{7}$ Kijūrō would go on to study law at the Imperial University of Tokyo. Nevertheless, although Shinjirō was a wealthy farmer, it was remarkable that he sent both Taira and Kijūrō to university. Although today it is common to see parents so dedicated to their children's education, at the time he must have been regarded as quite odd.

There is an episode that illustrates Shinjirō's devotion to his children's education. In later years, when Kijūrō was appointed vice-minister for foreign affairs, a reporter for the Osaka Asahi Shimbun came to interview Shinjirō. As the reporter described it, the father made his appearance supported by Misao and Setsu. A bony-looking figure, he was already 70 years old at that time and spoke while stroking his white beard. As Shinjirō recalled, some around the family had been unsupportive of his efforts, saying that 'commoners didn't need a fancy education'. Shinjirō, 
however, 'was prepared to dedicate the entirety of his finances to the education of his four children, in the hope that they would be of use to the nation'. ${ }^{8}$

Being raised in such a fortunate environment, Shidehara Kijūrō 'had hoped, since his school years, that he could one day become a diplomat'. It so happened that, while he was at the Imperial University of Tokyo in 1893 , an exam system for the diplomatic service was established by individuals including Hara Takashi, the head of the International Trade Bureau at the Ministry of Foreign Affairs and future tenth prime minister of Japan. However, Shidehara was diagnosed with thiamine deficiency in his fourth year of university and was unable to take the exam. Thus, following his graduation in 1895, Shidehara initially worked at the Bureau of Mining at the Ministry of Agriculture and Commerce. This work, however, did not reflect his real interests. The following year he took the fourth diplomatic service exam. He was one of only four individuals to pass the exam at that time. Thus, Shidehara realised his long-held ambition of entering the diplomatic service. ${ }^{?}$

Fellow successful candidates included Koike Chōzō, who would later become director-general of the Political Affairs Bureau at the Ministry of Foreign Affairs. In fact, there were numerous important diplomatic figures who passed the exam around this period. For example, the seventh cohort of successful candidates included Honda Kumatarō (1874-1948), Tanaka Tokichi (1877-1961), Hanihara Masanao (1876-1934) and Obata Yūkichi (1873-1947). Later, Matsudaira Tsuneo (1877-1949) and Debuchi Katsuji would pass the eleventh exam, Saburi Sadao and Satō Naotake (1882-1971) would pass the fourteenth exam, and Hirota Kōki and Yoshida Shigeru would pass the fifteenth exam. Arita Hachirō (1884-1965) and Shigemitsu Mamoru would pass the eighteenth and twentieth exams, respectively.

Thus, Shidehara graduated from the Imperial University of Tokyo in 1895-the twenty-eighth year of Meiji. His alumni association, the Nihachi-kai (literally the '2-8 Club'), borrowed the reign date of that year for their name. Members of the association included Izawa Takio, the political scientist Onozuka Kiheiji (1871-1944), future governorgeneral of Taiwan Kamiyama Mitsunoshin (1869-1938), bureaucrat and politician Shimooka Chūji (1870-1925), campaigner and social statistician Takano Iwasaburō (1871-1949), Tanaka Seijirō (18721954), future prime minister Hamaguchi Osachi and Shidehara himself. 
Shidehara also took on the role of organising the association. These kinds of personal connections would become significant for Shidehara before long. ${ }^{10}$

It is said that Shidehara was devoted to his family and always made sure to attend the Buddhist memorial services held at Gantokuji temple in his hometown, even during his extremely busy years in the diplomatic service. How did such an individual start out as a diplomat? The following chapter outlines the first stages of Shidehara's career as a newly minted member of the diplomatic service, just before his initial appointment to the office of foreign minister.

\section{Endnotes}

1 The following discussion is based on the contents of a previously published essay. See Hattori Ryūji, 'Shidehara Kijūrō to 20 Seiki no Nihon' [Shidehara Kijūrō and 20th-century Japan], Shosai no Mado, no. 517 (September 2002): 19-23. See also Shidehara Peace Foundation, ed., Shidehara Kijūrō (Tokyo: Shidehara Peace Foundation, 1955), 7-21. I have compiled information on previous research on Shidehara and the status of historical materials in Hattori Ryūji, 'Shidehara Kijūrō', in Kingendai Nihon Jinbutsu Shiryō Jōhō Jiten [A reference book for historical material and information on modern-era Japanese figures], ed. Itō Takashi and Suetake Yoshiya (Tokyo: Yoshikawa Kōbunkan, 2004), $205-07$.

2 'Shidehara Taira-shi no Ohanashi kara' [A word from Mr Shidehara Taira], date unknown, in 'Shidehara Heiwa Bunko' [Shidehara Peace Library], Reel 13, Modern Japanese Political History Materials Room, National Diet Library.

3 For further details, see 'Shidehara-ke Bunsho' [Documents relating to the Shidehara household], Kadoma Municipal History Museum. Important Shidehara family documents are collected in Kadoma City, ed., Kadoma-shi-shi, Dai 3 Kan: Kinsei Shiryō Hen [A history of Kadoma City, vol. 3: Early modern historical documents] (Kadoma: Kadoma City, 1997). Several texts on local government history have used this work as a primary historical source, including Kadoma Town History Editing Committee, ed., Kadoma-cho Shi [A history of the town of Kadoma] (Kadoma: Kadoma Town Office, 1962); Kadoma City, ed., Kadoma-shi-shi, Dai 4 Kan: Kinsei Honbun Hen [A history of Kadoma City, vol. 4: Overview of the early modern era] (Kadoma: Kadoma City, 2000). According to Kadoma City, Kadoma-shi-shi, Dai $4 \mathrm{Kan}$, in the Hōreki era, the Shidehara family rapidly increased their holdings and shifted from manual management to landowner management. The documents on inheritance and marriage proposals are contained in Kadoma City, Kadoma-shi-shi, Dai 3 Kan, and are also fascinating from a sociohistorical perspective.

4 Shidehara Taira, 'Tsushima Mondai' [The Tsushima problem], Chōsen Gakuhō, no. 1 (May 1951): 1. Taira also discusses the Tsushima problem from the perspective of Japanese-Korean relations in Shidehara Taira, Chōsen Shiwa [A discussion of Korean history] (Tokyo: Fuzanbō, 1924), 159-215.

5 Of course, all this must have been unexpected for Taira. In middle school, Tanzan was far from a model student. He had to repeat one year twice, so it took him seven years to finish middle school. Taira would have been quite surprised to be praised by, and even receive an offer of publication from, a student such as Tanzan. Human relationships are full of strange twists. In any case, Daitóa no Seiiku [The development of Greater East Asia] was published in 1941, three days before the attack on Pearl Harbor. Taira died in 1953 and did not live to see the formation of the Ishibashi cabinet three-and-a-half years later.

Alongside the aforementioned books, Shidehara Taira's numerous works include Joshi Kyoiku [Women's education] (Tokyo: Shūeidō, 1898); Nantō Enkaku-shi Ron [Discourse on the history of the southern islands] (Tokyo: Fuzanbō, 1899); Kyöiku Manpitsu, Zen [Some thoughts on education, 
complete ed.] (Tokyo: Kinkōdō Shoseki, 1902); Nichi-Ro-Kan no Kankoku [Korea between Japan and Russia] (Tokyo: Hakubunkan, 1905); Kankoku Seisö-shi [A chronicle of Korean political troubles] (Tokyo: Sanseidō, 1907); Gakkō Ron [A discourse on school] (Tokyo: Dōbunkan, 1909); 'Kantō Kokkyō Mondai' [The problem of the Kantō national border], in Tōyōkyō-kai Chōsa-bu Gakujutsu Hōkoku [The Oriental Association Investigation Department scholarly report], ed. Tōyōkyō-kai, vol. 1 (Tōyōkyō-kai, 1909), 207-36; 'Java oyobi "Borneo" Shisatsu Hōkoku' [Observation report on Java and 'Borneo'], Imin Chōsa Hōkoku, no. 6, (March 1911): 387-400; Sekai Shōkan [Small view of the world] (Tokyo: Hōbunkan, 1912); Nikkan-Kankei yorino Taishü Kenkyū [A study of Tsushima, drawing on the Japan-Korea relationship] (Hiroshima: Hiroshima Higher Normal School Geography and History Association, 1913); Manshükan [My view on Manchuria] (Tokyo: Hōbunkan, 1916); 'Wakou nitsuite' [On the Japanese pirates of the middle ages], in Zoku Shiteki Kenkyü [Historical research, continued], ed. Society of Historical Research (Tokyo: Fuzanbō, 1916), 1-21; Shōseinen no Hanzai Bōatsu Seisaku nitsuite [On policy to prevent youth crime] (Tokyo: Ministry of Home Affairs Bureau for Regions, 1917); Chōsen Kyöikuron [Discourse on education in Korea] (Tokyo: Rokumeikan, 1919); Sekai no Hensen wo Miru [Examining global changes] (Tokyo: Fuzanbō, 1926); 'Taiwan niokeru Kin, Iō oyobi Sekitan no Tanken' [The search for gold, sulphur and coal in Taiwan], in Ichimura Hakase Koki Kinen Töyöshi Ronsō [Dr Shimura's 70th birthday commemorative essay collection on Eastern history], ed. Publication Society for an Eastern History Essay Collection Commemorating Dr Ichimura’s 70th Birthday (Tokyo: Fuzanbō, 1933), 395-434; 'Kokushi yori Mitaru 300 Nen Kinen' [Three-hundred-year commemoration as seen from the perspective of national history], in Taiwan Bunka-shi Setsu [A theory of Taiwanese cultural history], ed. Tainan Prefecture Mutual Prosperity Association (Tokyo: Tainan Support Association, 1935), 1-32; Napō Bunka no Kensetsu e [Toward the construction of a southern culture] (Tokyo: Fuzanbō, 1938); Kyōiku Kentō: Dai 1, Kyöiku Gyosei no Tokushitsu [Investigations in education: 1, the special characteristics of education administration] (Tokyo: Shinkōsha, 1938); 'Honpōjin to Taiwan' [The Japanese and Taiwan], in Andō Kyōju Kanreki Shukuga Kinen Ronbunshū [Prof. Andō’s 60th birthday commemorative essay collection], ed. Prof. Andō's 60th Birthday Commemorative Association (Tokyo: Sanseidō, 1940), 571-84; Köa no Shūyō [The cultivation of Asian development] (Tokyo: Meisedō Shoten, 1941); 'Nanpō Kensetsu no Bunka Taisaku' [Cultural measures for southern construction], in Nanpō ShinKensetsu Köza [Course for new construction in the southern region], ed. Southern Region Research Association (Tokyo: Osakayagō Shoten, 1943), 55-78; 'Oki no Awa' [The foam offshore], in Okinawa Bunka Sōsetsu [Theories on Okinawan culture], ed. Yanagita Kunio (Tokyo: Chuōkōronsha, 1947), 5-22; Kyokutō Bunka no Köryū [Cultural exchange in the Far East] (Tokyo: Sekishoin, 1949); Bunka no Kensetsu [The construction of culture] (Tokyo: Yoshikawa Kōbunkan, 1953); Shidehara Taira, Kokushi-jō Nanyō Hatten no Ichimen [An aspect of the development of the South Sea in national history], ed. Konishi Tatehiko (Tokyo: Nanyō Keizai Kenkyūjo, 1941).

Of these, Nichi-Ro-Kan no Kankoku was reproduced in Literature on Korean Studies Research Institute, ed., Kyūkanmatsu Nittei Shinryakyu Shiryō Sösho IV: Seiji-hen 5 [Collected historical documents on the end of old Korea and the invasion of the Japanese empire IV: Politics volume 5] (Seoul: Aseamunkasya, 1984), 1-221. Chösen Kyöikuron was also reprinted in Watanabe Manabu and Abe Hiroshi, eds, Nihon Shokuminchi Kyoiku Seisaku Shiryo Shusei (Chōsen-hen) [Compilation of historical documents concerning Japanese colonial education policy (Korean section)], vol. 25 (Tokyo: Ryūkei Shosha, 1989). Gakkō Ron was reprinted in Ishikawa Matsutarō, ed., Kindai Nihon Gakkō Kyōiku-ron Köza, 5: Gakkō-ron [A course on modern Japanese school education discourse, 5: Discourse on school] (Tokyo: Kress Shuppan, 2001). A chronological list and bibliographic catalogue are presented at the end of Bunka no Kensetsu. Shidehara Taira was also the editor of Naigai Jitsuyo Chizu, Nihon no Bu [Domestic and foreign practical maps, Japanese section] (Tokyo: Kyōeiki Shōsha Shoten, 1897); Naigai Jitsuyō Chizu, Sekai no Bu [Domestic and foreign practical maps, world section] (Tokyo: Kyōeiki Shōsha Shoten, 1897).

See also Ishibashi Tanzan Complete Works Compilation Committee, ed., Ishibashi Tanzan Zenshū [The complete works of Tanzan Ishibashi], vol. 15 (Tokyo: Tōyō Keizai Shinpōsha, 1972), 12-14.

6 Osaka Asahi Shimbun, evening edition, 30 October 1915.

7 Izawa Takio Biography Compilation Committee, ed., Izawa Takio [Takio Izawa] (Tokyo: Haneda Shoten, 1951), 37-38. 
8 Osaka Asahi Shimbun, evening edition, 30 October 1915.

9 Shidehara Kijūrō, Gaikō 50 Nen [Fifty years of diplomacy] (Tokyo: Chūōkōronsha, 1987), 225-27.

10 'Ni Hachi Dōsōkai Kiji' [2-8 club articles], in 'Shidehara Heiwa Bunko', Reel 7. Dr Asano Toyomi has kindly provided his assistance in this area. With respect to the Ni Hachi-Kai, details can be found in Suetake Yoshiya, Taishō-ki no Seiji Közō [The political structure of the Taishō era] (Tokyo: Yoshikawa Kōbunkan, 1998), 148-50. For further information, see Izawa Takio Biography Compilation Committee, Izawa Takio, 49; Izawa Takio Document Research Association, ed., Izawa Takio Kankei Bunsho [Documents relating to Izawa Takio] (Tokyo: Fuyō Shobō Shuppan, 2000), 478. 
This text is taken from Japan at War and Peace: Shidehara Kijürō and the Making of Modern Diplomacy, by Ryuji Hattori, published 2021 by ANU Press, The Australian National University, Canberra, Australia.

doi.org/10.22459/JWP.2021.01 